\section{Growth Stage, Auxin Type, and Concentration Influence Rooting of Virginia Pine Stem Cuttings}

\author{
Christopher L. Rosier, ${ }^{1}$ John Frampton, ${ }^{2}$ Barry Goldfarb, ${ }^{2}$ \\ Farrell C. Wise, ${ }^{3}$ and Frank A. Blazich ${ }^{4}$ \\ Department of Forestry, North Carolina State University, Raleigh, NC 27695-8002
}

Additional index words. vegetative propagation, growth stage, indole-3-butyric acid, 1naphthaleneacetic acid, Christmas trees, adventitious rooting, Pinus virginiana

\begin{abstract}
Seven concentrations of indole-3-butyric acid (IBA), seven concentrations of 1naphthaleneacetic acid (NAA), and a nonauxin control were tested over three growth stages to determine their ability to promote adventitious rooting of stem cuttings from 3- and 4-year-old stock plants of virginia pine (Pinus virginiana Mill.). Cuttings were harvested September 2000 (semi-hardwood), February 2001 (hardwood), June 2001 (softwood), and October 2001 (semi-hardwood), treated with auxin concentrations ranging from 0 to $64 \mathrm{~mm}$ and placed under intermittent mist in a greenhouse. Rooting percentage, percent mortality, number of primary roots, total root length, root symmetry, root angle, and root diameter were assessed following 16 weeks. Growth stage affected every rooting trait measured except root symmetry and diameter. Auxin type affected total root length and root diameter, while auxin concentration affected every rooting trait except root angle. The highest predicted rooting percentages $(46 \%)$ occurred when semi-hardwood cuttings were collected in September 2000 and treated with $7 \mathrm{~mm}$ auxin. Cuttings collected within the same growing season (2001) exhibited the highest predicted rooting percentage $(33 \%)$ when softwood cuttings were treated with $6 \mathrm{~mm}$ auxin. Semi-hardwood cuttings rooted in 2001 produced the greatest number of roots and root lengths. Root diameter was significantly greater when NAA rather than IBA was applied, especially at higher concentrations.
\end{abstract}

Virginia pine (Pinus virginiana) is the most commonly cultivated Christmas tree species in the Piedmont and Coastal Plain of North Carolina. The species is desirable as a Christmas tree because of its rapid growth ( 3 to 6 years to harvest), short needles, good branch structure for holding ornaments, and pleasant aromatic scent (Frampton, 2001). Other desirable traits include high survival following planting, vigorous response to shearing, and ability to grow on poor sites (Belanger and Bramlett, 1975). However, virginia pine has several significant problems, including poor form, extensive variability among seedlings, somewhat poor postharvest needle retention, and extreme susceptibility to the nantucket pine tip moth [(Rhyacionia

Received for publication 22 May 2003. Accepted for publication 17 Nov. 2003. This research was funded jointly by the North Carolina Agricultural Research Service, Raleigh, NC 27695-7643, including the Christmas Tree Genetics Program, a grant from the Golden Leaf Foundation, and the Eastern North Carolina Christmas Tree Growers Association. Special thanks are extended to Jimmy Prince, Steve Warren, and the entire staff at the N.C. State University Horticultural Crops Research Station, Clinton, for assistance in establishing and maintaining the research trial from which the stem cuttings were collected. From a thesis submitted by C.L.R. in partial fulfillment of the requirements for the MS degree.

${ }^{1}$ Former graduate research assistant. Currently technical forester, Smurfit-Stone Container Corp., Fernandina Beach, FL 32024

${ }^{2}$ Associate professor, Department of Forestry. ${ }^{3}$ Research scientist and project leader, MeadWestvaco Corp., Box 1950, Summerville, SC 29484.

${ }^{4}$ Professor, Department of Horticultural Science. frustrana Comstock(Lepidoptera: Tortricidae)] (Frampton, 2001). Because of these problems, Christmas tree growers in eastern North Carolina are only able to market $\approx 50 \%$ of the virginia pines planted (Frampton, 2001).

Currently, commercial growers of virginia pine Christmas trees are limited to seedlings propagated by seeds that have been collected from orchards originally established to enhance forest production and pulpwood characteristics (Belanger and Bramlett, 1975; Holifieldetal., 1991). However, there is interest in genetic improvement of virginia pine because of its potential market value as a Christmas tree. Research has shown that desirable traits such as height, stem straightness, foliage density, symmetry, and branches per whorl are under genetic control (Belanger and Bramlett, 1975; Brown at al., 1991; Meier and Goggans, 1977). More importantly, the retail value of virginia pine Christmas trees is under strong genetic control (Knoth et al., 2002). Thus, clones using rooted stem cuttings could improve quality of planting stock, and allow production of uniform trees resulting in greatly increased profits (Zobel and Talbert, 1984).

There is sparse information available on rooting stem cuttings of virginia pine. Brown et al. (1991) reported no significant variation in rooting percentages over collection date, while Snow and May (1962) observed that hardwood cuttings of virginia pine collected in December rooted better $(72 \%)$, than those collected in March (19\%). Further, Holifiled et al. (1991) found that hardwood cuttings collected in March rooted better $(46 \%)$ than softwood cuttings collected in June (3\%). selection and production of genetically superior
There is also little known about the effect of exogenous auxin applications on rooting stem cuttings of virginia pine. Snow and May (1962) reported that applying a solution of 25 mM indole-3-butyric acid (IBA) to hardwood cuttings collected in March increased rooting percentages, but this treatment had no effect when hardwood cuttings were collected in December. Holifield et al. (1991) reported that application of Hare's talc-based rooting powder (Hare, 1974) to stem cuttings increased rooting percentages except when softwood cuttings were collected and rooted in June.

Additional research is needed to improve understanding of factors affecting rooting of virginia pine stem cuttings. Therefore, the objectives of this study were to determine the optimal growth stage, type of auxin, and auxin concentrations for promoting adventitious root initiation and subsequent root development of stem cuttings from 3- to 4-year-old stock plants of virginia pine.

\section{Materials and Methods}

Virginia pine cuttings were collected from an open-pollinated progeny test established Fall 1997 and located at the North Carolina State University Horticultural Crops Research Station near Clinton. Stock plants had been propagated by seeds and cultured as Christmas trees (Johnson, 1991). Stem cuttings were harvested on 14 Sept. 2000 (semi-hardwood), 23 Feb. 2001 (hardwood), 12 June 2001 (softwood), and 3 Oct. 2001 (semi-hardwood). Two terminal branch cuttings per tree were randomly selected from the upper third of the crown and the bases cut resulting in a minimum length of $13 \mathrm{~cm}$. Following collection, the cuttings were wrapped immediately in moist paper towels, placed on ice, and transported to Raleigh, N.C., where they were stored overnight at $4{ }^{\circ} \mathrm{C}$. All cuttings were set (inserted into the rooting medium) the day following collection.

Seven IBA and seven NAA (1-naphthaleneacetic acid) concentrations $(1,2,4,8,16,32$, or $64 \mathrm{~mm}$ ) and a solvent control were utilized. For each concentration, the auxin was dissolved into a 50\% isopropyl alcohol-deionized water solution. The prepared auxin solutions were then stored at $4{ }^{\circ} \mathrm{C}$ in opaque bottles and used within $2 \mathrm{~d}$.

Rooting was conducted in a propagation greenhouse located at the Horticulture Field Laboratory, Raleigh. Before being set into the rooting medium, cuttings were re-cut from the bases to a length of $9 \mathrm{~cm}$ and auxin was applied for $3 \mathrm{~s}$ to the basal $1.5 \mathrm{~cm}$. Cuttings for the control treatment were dipped into a $50 \%$ isopropyl alcohol-deionized water solution. Needles were not removed before or after auxin treatments were applied. Treated cuttings were air-dried for a minimum of $15 \mathrm{~min}$ before being inserted to a $3 \mathrm{~cm}$ depth into a rooting medium of 3 horticultural perlite : 2 peat (by volume). Cuttings were rooted in individual $164-\mathrm{cm}^{3} \mathrm{cells}$ (Ray Leach SC-1-Super cells; Steuwe and Son, Inc., Corvallis, Ore.).

During the rooting period, cuttings were maintained under intermittent mist using a Grower Junior(McConkey Co., Sumner, Wash.) 
overhead boom irrigation system. Frequency of mist application was controlled based on relative humidity $(\mathrm{RH})$ and time of day. As $\mathrm{RH}$ in the rooting greenhouse decreased, the frequency of mist application increased; however, mist application was less frequent during the night decreasing from an average of one mist cycle every 6 min (during the day) to an average of one mist cycle every 60 min (at night). Flow rate per mist cycle was constant over the 4-

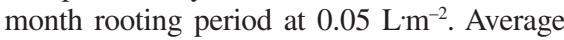
day/night temperatures in the greenhouse were $25.5 \pm 2 / 20.0 \pm 2{ }^{\circ} \mathrm{C}$ for semi-hardwood cuttings collected in 2000 , and $25.0 \pm 2 / 19.4 \pm 2^{\circ}$ $\mathrm{C}, 26.1 \pm 2 / 20.5 \pm 2{ }^{\circ} \mathrm{C}$, and $24.4 \pm 2 / 19.4 \pm 2$ ${ }^{\circ} \mathrm{C}$, respectively, for hardwood, softwood, and semi-hardwood cuttings collected in 2001.

Rooting percentage, percent mortality, number of primary roots, total root length, root system symmetry, root angle, and root diameter were recorded following 16 weeks in the greenhouse. The latter five traits were assessed only on cuttings that rooted. A cutting was considered rooted if a minimum of one root $\geq 1 \mathrm{~mm}$ in length was present. A cutting with two roots was considered to have a symmetrical root system when the angle between the roots was $>135^{\circ}$, using the stem center as the vertex (Frampton et al., 1999). Cuttings with three or more roots were scored as symmetrical if the angle between the two roots that were farthest apart was $<135^{\circ}$. Cuttings with one root were scored as having asymmetrical root systems. Root angle was used to determine the percentage of positively geotropic roots for each cutting. Root angle was defined as the percentage of roots that formed an angle $<60^{\circ}$ with an extension of the cutting's stem. Root diameter was measured on a subsample $(n=60)$ of each auxin type with cuttings randomly selected over all auxin concentrations within each of the four setting periods. Root diameter of every primary root was measured $1 \mathrm{~cm}$ from the base of the cutting to the nearest $0.5 \mathrm{~mm}$.

The experimental design for cuttings collected at each growth stage was a randomized complete block. There were eight blocks of eight cuttings per auxin treatment within each block for a total of 960 cuttings per growth stage. For each growth stage, the entire study was surrounded by a row of border cuttings.

Analyses of variance (ANOVAs) were conducted using the General Linear Models procedure of the Statistical Analysis System version 8.1 (SAS Institute, Inc., 1999). Growth stage, block within growth stage, auxin type, auxin concentration, auxin concentration squared, and all two- and three-way interactions (other than those involving block) were sources of variation. Transformations of the dependent variables (rooting traits) were investigated to increase homogeneity among treatment variances. Several transformations were tested including the square root, the arcsine of the square root, and a range of transformations using the Box and Cox (1964) procedure that varied $\lambda$ from -1.0 to +1.0 in increments of 0.25 . The method yielding the smallest differences among treatment variances was selected for each dependent variable. Once the most appropriate dependent variable transformation was selected, $\log$ and square root transformations of the independent variables (concentration and concentration squared) were compared to no transformation. The model yielding the highest $R^{2}$ value was reported for each dependent variable.

Despite employing the appropriate data transformations and including squared terms for concentration, least-squares regression approach failed to adequately define the relationship between concentration and dependent variables. Therefore, nonlinear regression techniques were employed by regressing each dependent variable on treatment means (concentration or auxin type by concentration) using the NLIN procedure of the Statistical Analysis System Version 8.1 (SAS Institute, Inc., 1999). The double exponential model (Rawlings et al., 1998), modified by two constants ( $\mathrm{A}$ and $\mathrm{B})$, was used: trait $=\theta_{1}\left(\mathrm{Be}_{(-\theta 2}\right.$ $\left.-e_{(-\theta 1 \times \text { concentration })}\right) /\left[\mathrm{A}\left(\theta_{1}-\theta_{2}\right)\right]$, where $\mathrm{e}=$ base of natural logarithm, $\theta_{1}, \theta_{2}, \mathrm{~A}$, and $\mathrm{B}$ $=$ regression coefficients, and concentration $=$ auxin coefficients in mM.

The least-squares linear regression approach using the General Linear Model procedure of the Statistical Analysis System version 8.1 (SAS Institute, Inc., 1999) adequately defined the relationship between concentration and root diameter. The model employed was root diameter $=$ intercept $+\mathrm{A} \times \log ($ concentration $)$
$+\mathrm{B} \times \log \left(\right.$ concentration $\left.^{2}\right)$, where $\mathrm{A}$ and $\mathrm{B}=$ regression coefficients.

Estimated parameters for both the nonlinear and linear regressions are presented in Rosier (2003).

\section{Results}

ANOVAs and transformations of the independent and dependent variables for all rooting traits are presented in Table 1 .

Rooting percentage. Rooting percentage was significantly affected by growth stage, block within growth stage, concentration, concentration squared, and the interaction between concentration squared and growth stage (Table 1). No significant differences were detected for auxin type $(P=0.56)$, so data for IBA and NAA were averaged over each growth stage for nonlinear regression analysis.

For semi-hardwood cuttings set in 2000 , the greatest overall predicted rooting percentage (47\%) occurred when cuttings were treated with 6 mm auxin (Fig. 1A). Hardwood and softwood cuttings set in 2001 reached their maximal predicted rooting percentages $(23 \%$ and $32 \%$, respectively) at $7 \mathrm{~mm}$. The highest predicted rooting percentage $(24 \%)$ for semi-hardwood cuttings set in 2001 was at $17 \mathrm{~mm}$.

Percentmortality. Percent mortality was significantly affected by growth stage, block within growth stage, concentration, and concentration squared (Table 1). Because no significant differences were detected for auxin type $(P=0.73)$ or its interactions, data were averaged over auxin type for nonlinear regression analysis. Predicted percent mortality decreased from $16 \%$ in the controls to $10 \%$ at $2 \mathrm{~mm}$ and then increased with increasing concentrations, reaching a maximum of $42 \%$ at $64 \mathrm{~mm}$ auxin (Fig. 1B)

Number of primary roots. Primary root production was significantly affected by the main effects of block within growth stage, concentration, and concentration squared (Table 1). There also was a significant interaction between concentration squared and growth stage. No significant differences were detected for auxin type ( $P=0.41)$ or its interactions, so that IBA and NAA data were averaged for nonlinear regression analysis. For semi-hardwood cut-

Table 1. ANOVA results for traits assessed in a rooting trial of virginia pine stem cuttings collected from 3- and 4-year-old stock plants.

\begin{tabular}{|c|c|c|c|c|c|c|c|}
\hline & $\begin{array}{c}\text { Rooting } \\
(\%)\end{array}$ & $\begin{array}{c}\text { Mortality } \\
(\%)\end{array}$ & $\begin{array}{l}\text { Primary } \\
\text { roots } \\
\text { (no.) }\end{array}$ & $\begin{array}{c}\text { Total } \\
\text { root } \\
\text { length }\end{array}$ & $\begin{array}{c}\text { Root } \\
\text { symmetry }\end{array}$ & $\begin{array}{l}\text { Root } \\
\text { angle }\end{array}$ & $\begin{array}{c}\text { Root } \\
\text { diam }^{2}\end{array}$ \\
\hline Y transformation & Arcsine square root & Square root & None & Square root & $\log$ & None & None \\
\hline $\mathrm{X}$ transformation & $\log$ & None & $\log$ & $\log$ & $\log$ & None & $\log$ \\
\hline Growth stage & $*$ & $*$ & NS & $*$ & NS & $*$ & NS \\
\hline Block (Growth stage) & $*$ & $*$ & $*$ & NS & NS & NS & --- \\
\hline Auxin type & NS & NS & NS & NS & NS & NS & $*$ \\
\hline Growth stage $(\mathrm{GS}) \times$ auxin $(\mathrm{A})$ & NS & NS & NS & $*$ & NS & NS & NS \\
\hline Concentration $(\mathrm{C})$ & $*$ & $*$ & $*$ & $*$ & $*$ & NS & $*$ \\
\hline $\mathrm{C}^{2 \mathrm{y}}$ & $*$ & $*$ & $*$ & NS & $*$ & NS & NS \\
\hline $\mathrm{C} \times \mathrm{GS}$ & NS & NS & NS & NS & NS & NS & NS \\
\hline $\mathrm{C}^{2} \times \mathrm{GS}$ & $*$ & NS & $*$ & $*$ & NS & NS & NS \\
\hline $\mathrm{C} \times \mathrm{A}$ & NS & NS & NS & NS & NS & NS & $*$ \\
\hline $\mathrm{C}^{2} \times \mathrm{A}$ & NS & NS & NS & NS & NS & NS & NS \\
\hline $\mathrm{C} \times \mathrm{GS} \times \mathrm{A}$ & NS & NS & NS & NS & NS & NS & NS \\
\hline $\mathrm{C}^{2} \times \mathrm{GS} \times \mathrm{A}$ & NS & NS & NS & NS & NS & NS & NS \\
\hline
\end{tabular}

${ }^{\text {z }}$ Root diameter was only measured on a subsample. A dash indicates this effect was not measurable due to the experimental design of the subsample.

${ }^{\mathrm{y}} \mathrm{C}^{2}=$ auxin concentration squared.

Ns, * Nonsignificant or significant at $P<0.05$, respectively. 

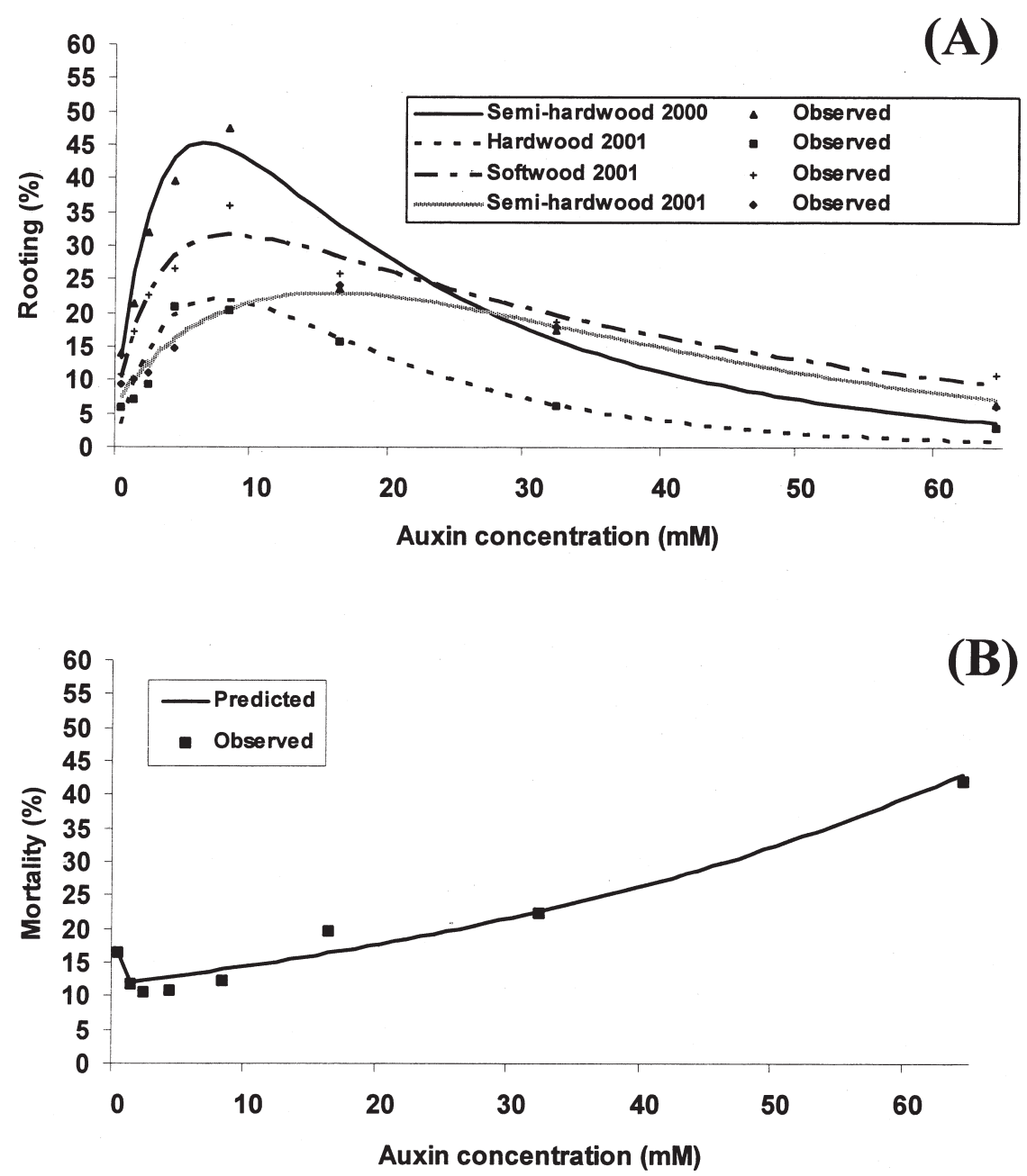

Fig. 1. Effects of growth stage and auxin concentration on (A) rooting percentage and (B) percent mortality of virginia pine stem cuttings. Response means were averaged over IBA and NAA. For percent mortality, growth stage responses were averaged over four collection periods. Rooting percentage $R^{2}$ values were $0.91,0.88,0.94$, and 0.97 for semi-hardwood 2000, hardwood 2001, softwood 2001, and semi-hardwood 2001 cuttings, respectively. Percent mortality $R^{2}$ value was 0.91 .

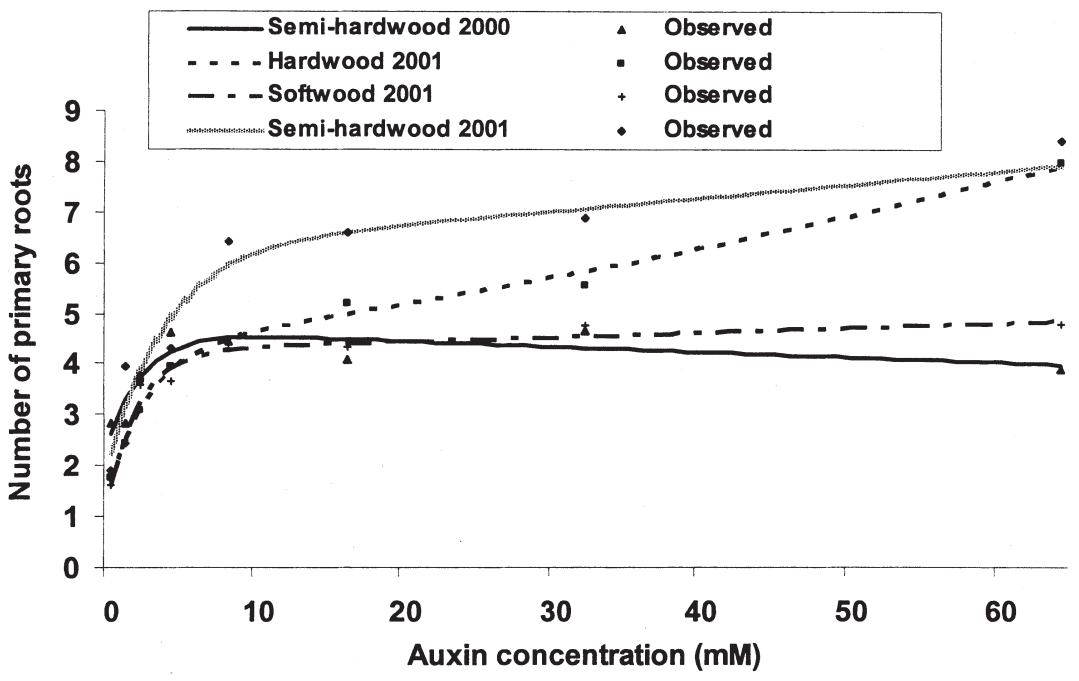

Fig. 2. Effects of growth stage and auxin concentration on primary root production in virginia pine stem cuttings. Response means were averaged over IBA and NAA. $R^{2}$ values were $0.87,0.99,0.97$, and 0.95 for semi-hardwood 2000, hardwood 2001, softwood 2001, and semi-hardwood 2001 cuttings, respectively.

tings set in 2000, the greatest predicted number of primary roots (4.6) occurred at $6 \mathrm{~mm}$ auxin (Fig. 2). For cuttings rooted in 2001, primary

root productionincreased up to concentrations of $8 \mathrm{~mm}$ and then leveled off (softwood and semihardwood cuttings) or continued to increase with increased auxin concentration (hardwood cuttings). At $8 \mathrm{~mm}$, predicted primary root production was 4.2, 4.3, and 6.5 for hardwood, softwood, and semi-hardwood cuttings set in 2001, respectively.

Total root length. The main effects of growth stage and concentration as well as the interaction between growth stage and auxin type significantly affected total root length (Table 1). The interaction between concentration squared and growth stage was also significant. Due to these interactions, separate nonlinear regression analyses were conducted for each auxin and growth stage combination.

When IBA was applied, predicted total root lengths for semi-hardwood cuttings set in 2000 and 2001 increased rapidly to a maximum (194 $\mathrm{mm}$ at $6 \mathrm{~mm}$ IBA and $473 \mathrm{~mm}$ at $17 \mathrm{~mm}$ IBA, respectively) (Fig. 3A). When IBA was applied to softwood cuttings, predicted total root lengths increased rapidly from $24 \mathrm{~mm}$ in the control to $369 \mathrm{~mm}$ at $20 \mathrm{~mm}$ before leveling off and reaching a maximum of $412 \mathrm{~mm}$ at $64 \mathrm{~mm}$. With hardwood cuttings, predicted total root lengths continued to increase throughout the range of auxin concentrations from the control $(0 \mathrm{~mm})$ to $64 \mathrm{~mm}(304 \mathrm{~mm})$.

When NAA was applied to the bases of the semi-hardwood cuttings, predicted total root lengths peaked at $10 \mathrm{~mm}$ in $2000(274 \mathrm{~mm})$ and $22 \mathrm{mmin} 2001(369 \mathrm{~mm})$ before decreasing with increased auxin concentrations (Fig. 3B). With softwood cuttings, predicted total root length continued to increase with increases in auxin concentration from the controls $(111 \mathrm{~mm})$ to 64 $\mathrm{mm}(615 \mathrm{~mm})$. For hardwood cuttings, predicted total root length increased rapidly from the control $(0 \mathrm{~mm})$ to $8 \mathrm{~mm}(170 \mathrm{~mm})$ before increasing slightly with increased concentrations.

Root symmetry. Concentration and concentration squared significantly affected root symmetry (Table 1). No significant differences were detected for auxin type or its interactions; therefore, IBA and NAA data were averaged for nonlinear regression analysis. Root symmetry increased rapidly from the controls $(4 \%)$ to 8 $\mathrm{mm}(41 \%)$ before leveling off and only slightly increasing with increased auxin concentrations (Fig. 4).

Root angle. Growth stage was the only source of variation that significantly affected root angle (Table 1). The highest predicted percentage of positively geotropic roots (87\%) occurred in the softwood cuttings. There was no difference between the predicted values for hardwood (79\%) and semi-hardwood cuttings set in 2001 (79\%), however, semi-hardwood cuttings collected in 2000 produced the fewest number of positively geotropic roots $(66 \%)$.

Root diameter. Root diameter was affected by the main effects of auxin, concentration, and the interaction between concentration and auxin (Table 1). When IBA was applied to the bases of cuttings, the predicted average for root diameter increased from $1 \mathrm{~mm}(0.6 \mathrm{~mm})$ to 32 $\mathrm{mm}(1.5 \mathrm{~mm})$, before decreasing at $64 \mathrm{~mm}(1.4$ $\mathrm{mm}$ ) (Fig. 5). When NAA was applied to the bases of cuttings, the predicted average for root diameter increased slowly from $1 \mathrm{~mm}(1.1 \mathrm{~mm})$ to $16 \mathrm{~mm}(1.4 \mathrm{~mm})$, before increasing rapidly at $64 \mathrm{~mm}(2.7 \mathrm{~mm})$. 

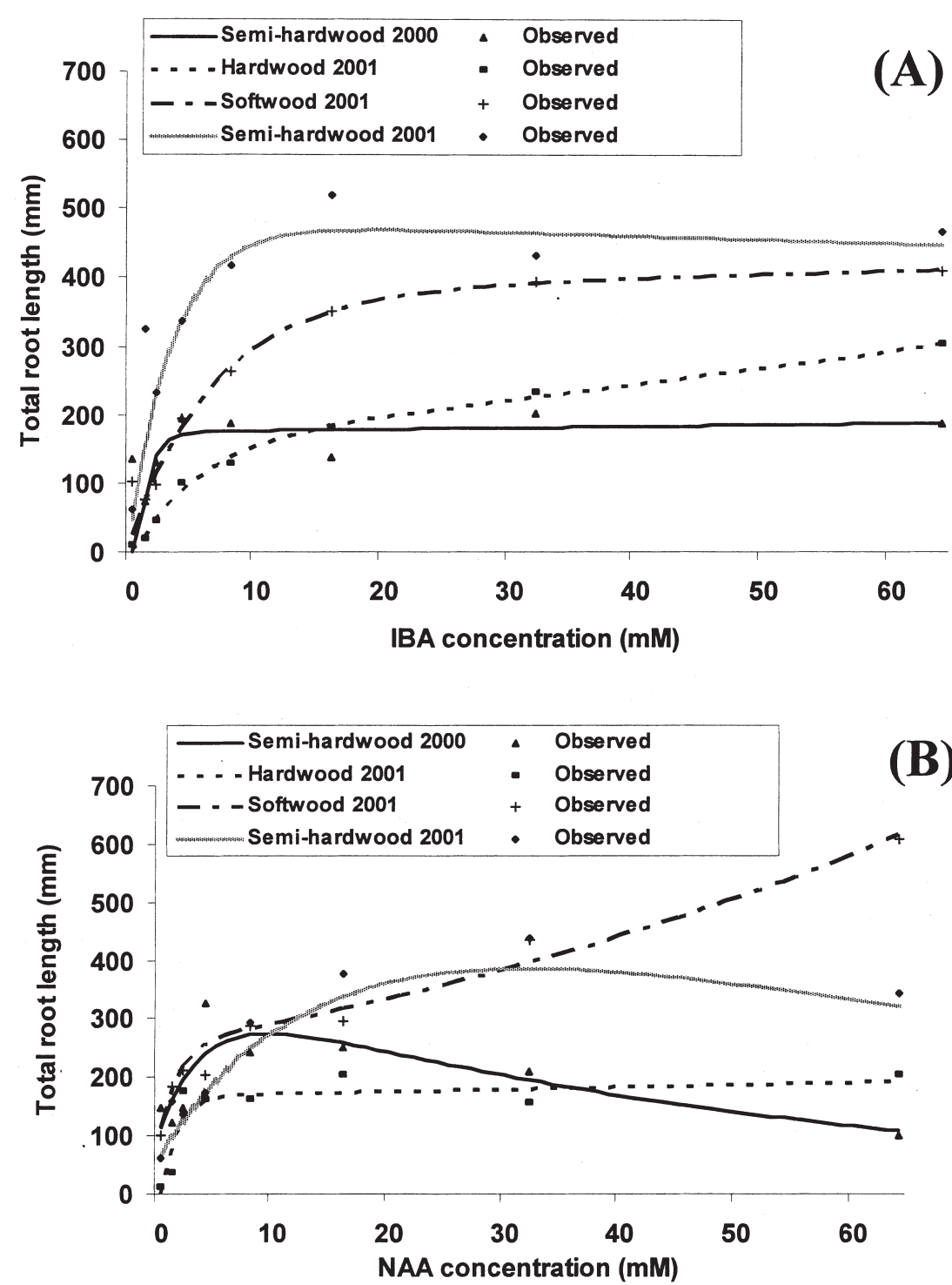

Fig. 3. Effects of growth stage and (A) IBA or (B) NAA concentration on the total root lengths of virginia pine stem cuttings. For IBA, $R^{2}$ values were $0.82,0.99,0.99$, and 0.86 for semi-hardwood 2000 , hardwood 2001, softwood 2001, and semi-hardwood 2001 cuttings, respectively. For NAA, $R^{2}$ values were 0.74 0.85, 0.97, and 0.95 for semi-hardwood 2000, hardwood 2001, softwood 2001, and semi-hardwood 2001 cuttings, respectively.

\section{Discussion}

Growth stage and age effects. Growth stage (i.e., degree of wood maturity) of the stock plants from which stem cuttings were taken greatly affected rooting. This phenomenon has been reported previously for cuttings of several other pine (Pinus L.) species (Boeijink and van Broekhuizen, 1974; Cameron, 1968; Kiang et al., 1974; Lanphear and Meahl, 1963) and is attributable to morphological and physiological characteristics of the stock plant at time of cutting collection (Hartmann et al., 2002).

In this study (and others), differences among the field conditions under which the cuttings developed, as well as differences in the greenhouse environment under which the cuttings rooted, were confounded with growth stages. In addition, the 2000 semi-hardwood cuttings were one growing season younger than the other three growth stages. Age appeared to have a greater influence on rooting than growth stage since the rooting percentage of semi-hardwood cuttings set in 2000 was about twice that of semihardwood cuttings set in 2001, and considerably higher than those of hardwood and softwood cuttings set in 2001 . The younger cuttings also appeared to be more sensitive to increases in auxin concentration (Figs. 1 and 3B). Marino (1982) noted that, for nonhedged material, the threshold age at which maturation increases and rooting decreases in some southern pine species occurs around age three. If this is true in virginia pine, then this phenomenon, at least partially, explains the difference in rooting between the cuttings set in 2000 (3-year-old material) and those set in 2001 (4-year-old material). It is also possible that the later collection date for semihardwood cuttings in 2001 (Oct.), as compared to those collected in 2000 (Sept.), adversely affected rooting percentage.

Hardwood cuttings rooted poorest of the three growth stages tested(Fig. 1). These cuttings also displayed more terminal budbreak (84\%) before rooting than the other growth stages (4\% and $1 \%$ for softwood and semi-hardwood cuttings, respectively). These results agree with those of Snow and May (1962) who also found that hardwood cuttings of virginia pine set in March rooted much poorer (19\%) than semi-hardwood cuttings (72\%). Softwood cuttings rooted best of the cuttings collected from 4-year-old stock plants. However, propagators should use younger stock plants, if possible, and it is not clear if softwood cuttings from younger material will also root better than semi-hardwood cuttings.

Since callus formation in semi-hardwood cuttings was still occurring after 16 weeks, some $(n=196)$ of these cuttings were re-set into fresh medium for an additional 6 weeks. Fifty-two percent of these cuttings developed at least one root, suggesting that a rooting period $>16$ weeks may be required for semi-hardwood virginia pine cuttings. Other researchers have reported that 8- to 9-year-old virginia pine cuttings required 7 to 9 months to develop roots (Snow and May, 1962).

Auxin type and concentration effects. Auxin type did not significantly affect rooting percentage or primary root production. However, it significantly affected total root length. While this effect varied with growth stage, NAA generally induced longer root systems at optimal concentrations for rooting (Fig. 3). Further, NAA treated cuttings always produced larger diameters than cuttings treated with equivalent molar concentrations of IBA (Fig. 5). Visual inspections suggested that as the concentration of NAA increased, secondary root production began to decrease with very little at $32 \mathrm{~mm}$ and none at $64 \mathrm{~mm}$. As the concentration of IBA increased, secondary root formation decreased slowly, but was always present even at the highest concentration. Thus, the longer root systems produced by NAA treatment may result in a less fibrous root system.

Auxin concentration significantly affected most rooting traits (Table 1). Percent rooting increased significantly with increases in auxin concentration up to an optimum, before decreasing steadily (Fig. 1). Percent mortality generally increased from lower to higher concentrations. Root production increased rapidly to an optimum and then continued to increase slightly with increases in auxin concentration. An exception was root production for the 2000 semi-hardwood cuttings, which decreased slightly following the optimum (Fig. 2). Total root lengths increased rapidly at lower concentrations and then, generally, either showed little change or decreased slightly (Fig. 3). Root symmetry, not significantly affected by auxin type, also increased rapidly to an optimum, before leveling off with increased auxin concentrations (Fig. 4).

Higher concentrations of auxin (>16 mM) did not substantially produce a greater number of roots, but visual inspections suggested that it affected the origin of root initiation on the stem. When cuttings were treated with low levels of auxin, roots generally emerged directly from the callused basal area of the stem, whereas, higher concentrations caused an area of basal dieback with roots emerging above the dead tissue. This phenomenon was most pronounced in hardwood cuttings where, especially at the higher concentrations, numerous roots measuring only a few 


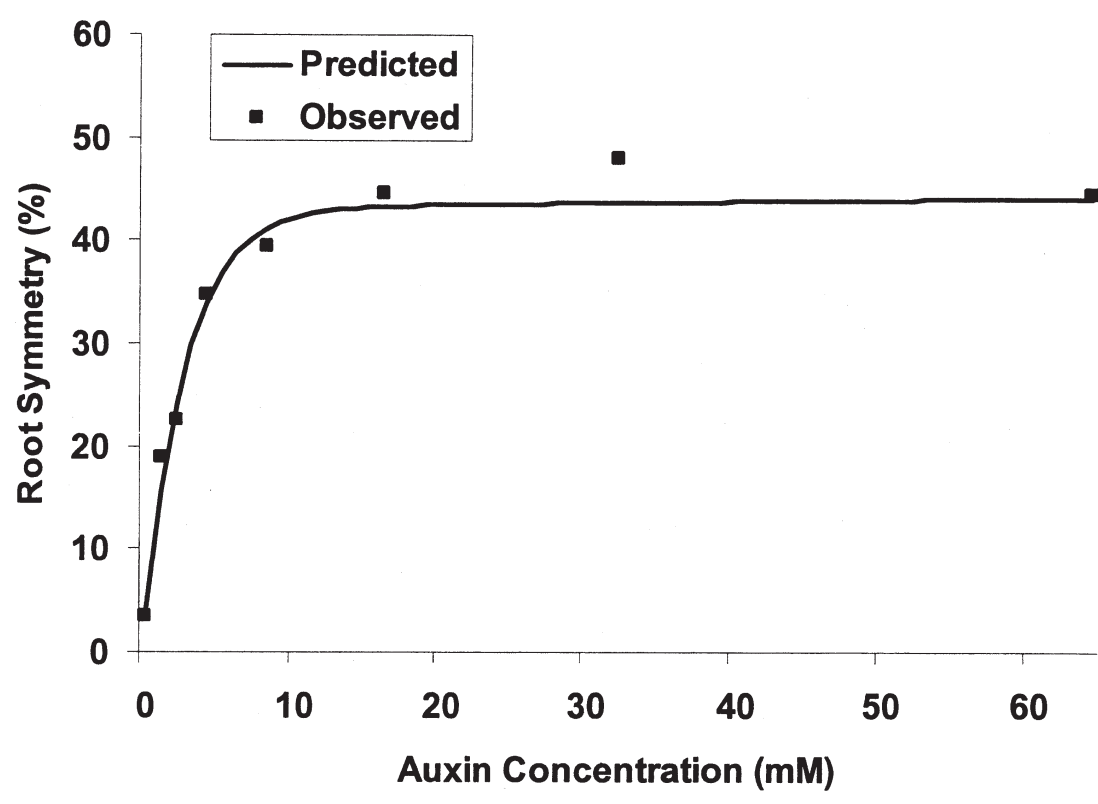

Fig. 4. Effect of auxin concentration on the percentage of symmetrical roots of virginia pine stem cuttings. Response means were averaged over IBA and NAA and four collection periods. $R^{2}$ value was 0.98 .

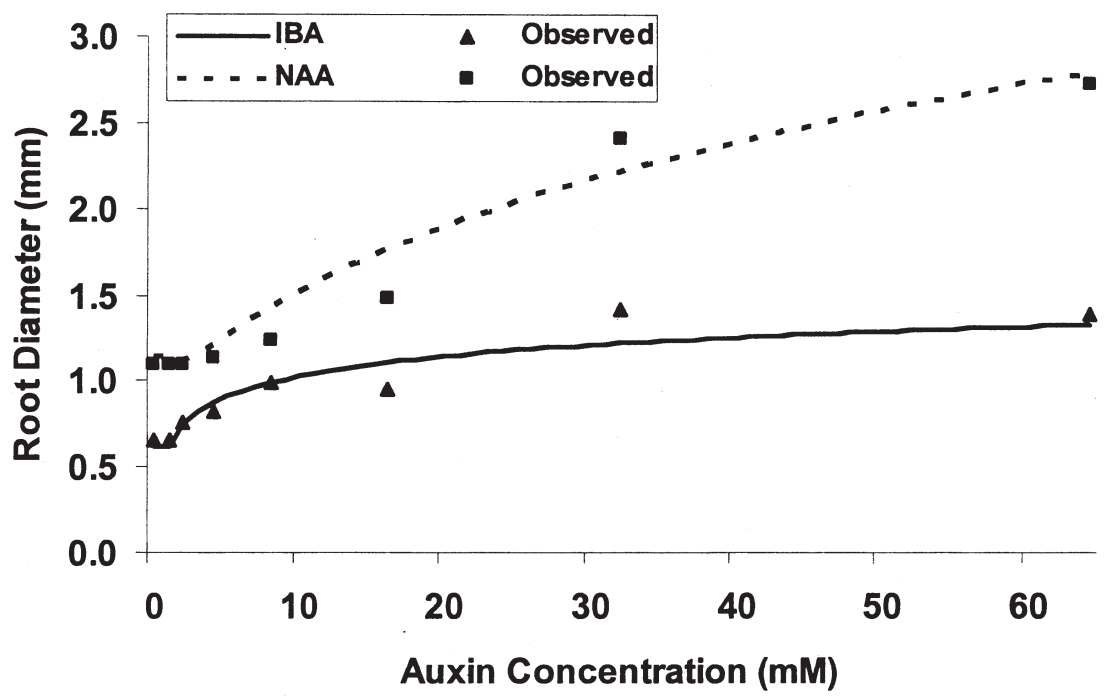

Fig. 5. Effects of auxin type and concentration on root diameter of virginia pine stem cuttings. $R^{2}$ values were 0.91 and 0.90 for IBA and NAA, respectively.

millimeters in length grew above dead tissue at the cutting base. As a result, primary root numbers in the hardwood cuttings were high while total root lengths, regardless of auxin type, were low.

While not presented herein, a study investigating combinations of auxin types was conducted simultaneously with the current study (Rosier, 2003). Nine combinations of three concentrations $(0,4$, and $16 \mathrm{~mm})$ of both IBA and NAA were tested in a factorial fashion. Generally, these combinations produced negative effects on the rooting traits assessed relative to the use of a single auxin.

Results from the current study should provide a basis for the advancement of vegetative propagation of virginia pine by stem cuttings. However, additional research is needed to develop a protocol that will further increase rooting percentages and enhance root development.
Since rooting of virginia pine cuttings appears to be extremely sensitive to stock plant age, management of hedged stock plants should be investigated to circumvent problems associated with maturation. This has proven to be an effective strategy for production of multiple juvenile shoots that root readily with several other pine species including loblolly pine ( $P$. taeda L.) and radiata pine ( $P$. radiata $D$. Don) (Bolstad and Libby, 1982; Fielding, 1954; Libby et al., 1972; Menzies and Klomp, 1988).

\section{Literature Cited}

Belanger, R.P. and D.L. Bramlett. 1975. Virginia pine as a Christmas tree. U.S. Dept. Agr. S.E. For. Expt. Sta. (Ashville, N.C.) Res. Note SE-223.

Boeijink, D.E. and J.T. van Broekhuizen. 1974. Rooting of cuttings of Pinus sylvestris under mist. N.Z. J. For. Sci. 4:127-132.

Bolstad, P.V. and W.J. Libby. 1982. Comparisons of radiata pine cuttings of hedge and tree-form origin after seven growing seasons. Silvae Genetica 31:9-13.

Box, G.E.P. and D.R. Cox. 1964. An analysis of transformations. J. Royal Stat. Soc. (Ser. B) 26:211-246.

Brown, G.F., Q. Holifield, J.L. Ford-Logan, and G.S. Foster.1991. Clonal variation in rooting ability of virginia pine, p. $187-195$. Proc. $21^{\text {st }}$ S. Forest Tree Improvement Conf.

Cameron, R.J. 1968. The propagation of Pinus radiata by cuttings. N.Z. J. Forest Sci. 13:78-89.

Fielding, J.M. 1954. Methods of raising monterey pine from cuttings in the open nursery. Austral. For. Timber Bur. Bul. 32.

Frampton, J. 2001. North Carolina's Christmas tree genetics program, p. $94-100$. Proc. $26^{\text {th }}$ S. Forest Tree Improvement Conf.

Frampton, L.J., B. Goldfarb, S.E. Surles, and C.C. Lambeth. 1999. Nursery rooting and growth of loblolly pine cuttings: Effects of rooting solution and full-sib family. S. J. Appl. For. 23:108-115.

Hare, R.C. 1974. Chemical and environmental treatments promote rooting of pine cuttings. Can. J. For. Res. 4:101-106

Hartmann, H.T., D.E. Kester, F.T. Davis, Jr., and R.L. Geneve. 2002. Hartmann and Kester's plant propagation: Principles and practices. 7th ed. Prentice Hall, Upper Saddle River, N.J.

Holifield, Q., J.L. Ford-Logan, G.S. Foster, and G.F. Brown.1991. Efficiency of hormonal treatments for the propagation of virginia pine by cuttings, p. $182-186$. Proc. $21^{\text {st }}$ S. Forest Tree Improvement Conf.

Johnson, J.E. 1991. Christmas tree production manual. Va. Coop. Ext. Serv., Blacksburg.

Kiang, Y.T., O.M. Rogers, and R.B. Pike. 1974. Vegetative propagation of eastern white pine by cuttings. N.Z. J. For. Sci. 4:153-160.

Knoth, J., J. Frampton, and R. Moody. 2002. Genetic improvement of virginia pine planting stock in South Carolina. HortTechnology 12:675-678.

Lanphear, F.O. and R.P. Meahl. 1963. Influence of endogenous rooting cofactors and environment on the seasonal fluctuation in root initiation of selected evergreen cuttings. Proc. Amer. Soc. Hort. Sci. 83:811-818.

Libby, W.J., A.G. Brown, and J.M. Fielding. 1972. Effects of hedging radiata pine on production, rooting, and early growth of cuttings. N.Z. J. For. Sci. 2:263-283.

Marino, T.M. 1982. Propagation of southern pines by cuttings. Proc. Intl. Plant Prop. Soc. 31:518-524.

Meier, R.J. and J.F. Goggans. 1977. Heritabilities of height, diameter and specific gravity of young virginia pine. For. Sci. 23:450-456.

Menzies, J. and P. Klomp. 1988. Effects of parent age on growth and form of cuttings, p. 18-41. In: M.I. Menzies, P. Aimers, and L.J. Whitehouse (eds.). Workshop on growing radiata pine from cuttings. N.Z. For. Res. Inst. Bul. 135.

Rawlings, J.O., S.G. Pantula, and D.A. Dickey. 1998. Applied regression analysis: A research tool. $2^{\text {nd }}$ ed. Springer-Verlag, New York.

Rosier, C.L. 2003. Factors affecting rooting of fraser fir (Abies fraseri) and virginia pine (Pinus virginiana) stem cuttings. MS thesis. N.C. State Univ., Raleigh.

SAS Institute, Inc. 1999. SAS/STAT user's guide. version $6.4^{\text {th }}$ ed. vols. $1-2$. SAS Inst., Inc.,Cary, N.C.

Snow, A.G. and C. May. 1962. Rooting of virginia pine cuttings. J. For. 60:257-258.

Zobel, B. and J.Talbert. 1984. Applied forest tree improvement. Wiley, Prospect Hill, Ill. 